\title{
THE EVOLUTION OF LOW COST CARRIERS IN AUSTRALIA
}

\author{
Panarat SRISAENG ${ }^{1}$, Glenn S. BAXTER ${ }^{2}$, Graham WILD ${ }^{3}$ \\ School of Aerospace, Mechanical and Manufacturing Engineering, RMIT University, \\ Melbourne, Australia 3001 \\ E-mails: ${ }^{1}$ s3125221@student.rmit.edu.au (corresponding author); ${ }^{2}$ glenn.baxter@rmit.edu.au; \\ 3graham.wild@rmit.edu.au
}

Received 30 June 2014; accepted 10 October 2014

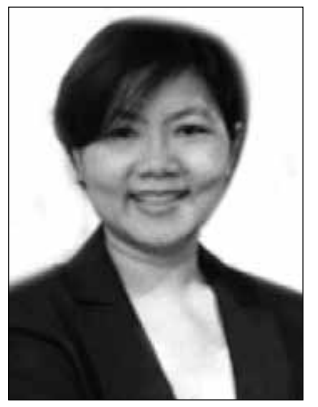

\section{Panarat SRISAENG}

Education: bachelor of economics, Chulalongkorn University, Bangkok, Thailand, 1993. Master of business economics, Kasetsart University, Bangkok, Thailand, 1998. Affiliations and functions: PhD (candidate) in aviation, RMIT University, School of Aerospace, Mechanical and Manufacturing Engineering.

Research interests: low cost airline management; demand model for air transportation; demand forecasting for air transportation.

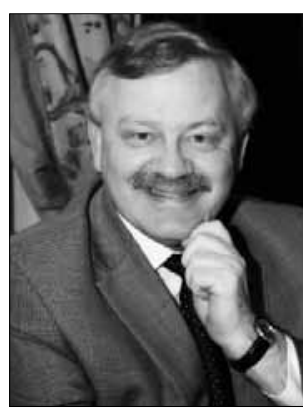

Glenn S. BAXTER, $P h D$

Education: bachelor of aviation studies, the University of Western Sydney, Australia, 2000. Master of aviation studies, the University of Western Sydney, Australia, 2002. PhD, School of Aviation, Griffith University, Brisbane, Australia, 2011.

Affiliations and functions: Lecturer in Aviation Management and Deputy Manager of Undergraduate Aviation Programs, at RMIT University, School of Aerospace, Mechanical and Manufacturing Engineering.

Research interests: air cargo handling and operations; airport operations and sustainability; supply chain management.

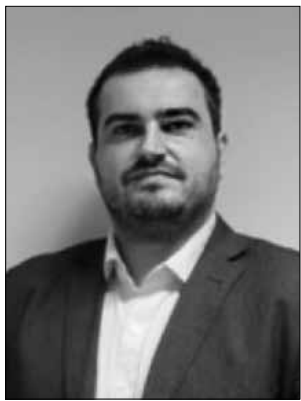

\section{Graham WILD, $P h D$}

Education: 2001-2004 - bachelor of science (Physics and Mathematics), Edith Cowan University. 2004-2005 - bachelor of science honours (Physics), Edith Cowan University. 2008 - Graduate Certificate (Research Commercialisation), Queensland University of Technology. 2006-2008 - master of science and technology (Photonics and Optoelectronics), the University of New South Wales. 2006-2010, PhD (Engineering), Edith Cowan University.

Affiliations and functions: 2010, Postdoctoral research associate, Photonics Research Laboratory, Edith Cowan University. 2011-2012, lecturer of aviation systems, Edith Cowan University. 2012 - present, senior lecturer in Aerospace and Aviation, RMIT University, School of Aerospace Mechanical and Manufacturing Engineering. Research interests: aircraft systems; aerospace vehicle structural health monitoring; optical fibres; sensing and instrumentation; sustainable aviation; aviation technology. Publications: author of 8 articles, 4 conference presentations.

Present position: 2014 - present, aviation program manager, RMIT University, School of Aerospace Mechanical and Manufacturing Engineering. 


\begin{abstract}
Due to the vast distances across the country as well as between urban centres, Australia is heavily reliant upon its air transport industry. Following deregulation of Australia's domestic air travel market on the $30^{\text {th }}$ October, 1990, low cost carriers have entered the market. Australia's LCC market has had three discrete phases. The first wave occurred between 1990 and 1993 and was subsequently followed by a duopoly period in 1994-1999. The second wave occurred between 2000 and 2006 and the final wave has been in the post-2006 period. This paper examines the evolution of Australia's domestic low cost carrier airline market and finds that by 2010, low cost carriers had captured around 64 per cent of the market. Following the evolution of the "Virgin Australia" business model from a low cost carrier to a full service network carrier, commencing in 2011, the low cost carrier's market share has declined significantly and is now around 31 per cent. "Jetstar" and "Tiger Airways" are the two major carriers presently operating in this market segment.
\end{abstract}

Keywords: Australia, airlines, business model, aviation policy, low-cost carriers.

\section{Introduction}

The vast size of the Australian continent, the country's varied and rugged topography, and scattered population present significant transport (and communication) challenges. Due to the vast distances across the country as well as between urban centres, Australia is heavily reliant upon its air transport industry (Nolan 1996). Australia's airline industry was born on connecting regional communities to the country's major cities (Baker, Donnet 2012). Also, the government historically tightly controlled Australia's air transport industry. In 1990, the Australian government commenced the deregulation of the country's domestic airline market process, permitting private competition, and privatising its interests in existing airlines (Nolan 1996). The government terminated the "Two Airline Policy", which had maintained a highly regulated duopoly in domestic interstate air transport, and permitted other airlines to compete with the established carriers in Australia's domestic airline market (Forsyth 2003; Nolan 1996).

Since the industry was deregulated, a number of low cost carriers (hereafter LCCs) have entered the Australian domestic air travel market - Impulse Airlines, Compass Airlines, both of whom subsequently collapsed, Jetstar Airways, Tiger Airways and Virgin Australia, though since 2011 the latter has moved to a full service network carrier (FSNC) business model. US-based Southwest Airlines pioneered the original LCC business model in 1971 (Daraban 2012) and it is still widely used around the world today (Alamdari, Fagan 2005; de Wit, Zuidberg 2012). LCCs are often regarded as one of the most successful business concepts that have happened within contemporary travel. The astute business model of offering significantly lower prices by eliminating all the extras in a short-haul flight, together with innovative cost-cutting measures, was successful in the USA as early as 1973 when Southwest Airlines operated its first lowcost flight (Kua, Baum 2004).

This paper examines the evolution of LCCs in Australia's domestic air travel market. The paper is structured as follows: section 2 presents the low cost carrier business model, section 3 reviews the evolution of Aus- tralia's domestic airline policy, section 4 examines the development of Australia's low cost carriers and section 5 provides concluding remarks on the research findings.

\section{Low cost carrier business model}

A low cost carrier is an airline that offers low air fares but eliminates all unnecessary services (Doganis 2006). The LCC business model is very simple: operate at the lowest possible cost and sell seats at low rates such that they stimulate demand and achieve high load factors (Fernie 2011).

LCCs focus on cost reduction in order to implement a price leadership strategy in the markets which they serve (Vidović et al. 2013). An airline's fleet size and fleet structure have a substantial impact on its operating costs (Klophaus et al. 2012). LCCs' costs are therefore minimized by operating a single-type aircraft fleet (Koch 2010). The use of a young and homogenous fleet of medium-sized aircraft (usually Boeing 737-700/800 or Airbus $320^{1}$ aircraft) normally results in a reduction of fuel, maintenance, staff costs and - if large orders at discounted prices are placed - capital costs (Ehmer et al. 2008). According to F. Alamdari and S. Fagan (2005), fleet commonality provides greater flexibility for cockpit and cabin crews, standardises the requirement for ground equipment, leads to lower maintenance costs, and reduces training requirements and costs. Only variable in-flight seating costs (and some fuel costs) increase when more passengers are carried. LCCs' unit costs are also reduced by selling tickets online and by implementing a high density seating configuration (Doganis 2006). High-density seating leads to lower unit costs, as fixed costs can be attributed to more seats and passengers (Fernie 2011). LCCs also often eliminate all kinds of free in-flight services, such as in-flight entertainment (IFE) and free meals in order to minimise their costs (Doganis 2006; Homsombat et al. 2014).

\footnotetext{
1 Airbus, for instance, offers the single-aisle A320 family compromising the A318, A319, A320 and A321 aircraft. These aircraft share the same pilot type rating, enabling flight crews to fly any of them with a single license endorsement (Klophaus et al. 2012).
} 
The LCCs often operate services from secondary airports (Chang, Hung 2013; Francis et al. 2006). LCCs often commence their services from secondary airports, which are normally located farther from the main urban area than primary airports. Strategically LCCs are endeavouring to broaden their traffic catchment area and increase their market shares by offering flights at lower air fares (de Wit, Zuidberg 2012). Apart from the lack of congestion at smaller airports, secondary airports usually charge lower fees than the more established airports and, where permitted, are more willing to co-finance the promotion of new routes. Using secondary airports not only reduces costs but actually enhances LCCs competitive advantage in several aspects. Firstly, using secondary airports overcomes slot availability problems allowing LCCs to design flight schedules that maximize fleet utilization (Barbot 2006). Nevertheless, lower air fares are crucial, because the accessibility to and from these often quite remote, secondary airports can be quite time consuming for passengers, which may make the LCC services quite unattractive to time-sensitive business passengers (de Wit, Zuidberg 2012). Accordingly, low air fares must be offered by the LCCs in order to attract sufficient price-sensitive passengers from larger traffic catchment areas (Pantazis, Liefner 2006).

Aircraft ground handling ${ }^{2}$ turnaround times and flight delays are also reduced by serving smaller, uncongested airports and by focusing on point-to-point flights (Pitt, Brown 2001; Koch 2010), often without providing any connections, thereby enabling an LCC to maximize the number of daily block hours and aircraft utilization (Ehmer et al. 2008). Successful LCCs also avoid operating from airports with congested airspace, runways, and taxiways (de Neufville 2006). Less congested secondary airports help airlines to maintain their flight schedules and avoid delay costs. By utilising less congested airports aircraft turnaround times can be optimised which helps keep costs low and increases operational efficiency and productivity. This is important because quick turnaround times enable LCCs to maximise aircraft use and minimise the time they are on the ground (Barrett 2004; Gillen, Lall 2004) and operating from airports with low levels of delays results in significant cost advantages for the LCCs (de Neufville 2008). Indeed, one of the key success factors of the LCC business model is the high daily aircraft utilization rate $^{3}$ and rapid ground handling

\footnotetext{
${ }^{2}$ When aircraft are on the ground in between flights they require various ground handling services to be performed, for example, aircraft loading/unloading; air cargo handling; lavatory services, and aircraft towing or pushback (Kazda, Caves 2007).

${ }^{3}$ The standard measure of aircraft productivity is the daily aircraft utilization rate which is the average number of daily block hours operated by each aircraft in the airline's fleet (Alamdari, Fagan 2005).
}

turnaround times (Goh 2005; Thanasupsin et al. 2010), which are very often less than 20 minutes in duration (Bieger, Agosti 2005). Furthermore, LCCs often use a "free seating" policy, since it encourages passengers to board quickly and thus helps them to avoid flight delays (Ehmer et al. 2008). Notwithstanding, even if secondary airports have dominated the LCCs' route network strategies, in recent years primary airports have slowly entered into their route systems. Thus, many LCCs now tend to adopt a mixed airport strategy. Operations are often generally based at prime hubs. From these hubs, these carriers primarily serve secondary airports (Alamdari, Fagan 2005).

LCCs are also able to reduce costs by avoiding airports that have expensive ground facility rents. LCCs often use older, less expensive terminal facilities, and, most importantly, optimise their terminal space more intensively so that they require less. LCCs also pay attention to their customers' car parking costs and other associated airport fees (de Neufville 2006).

The LCC business model is also often based around very short distance, point-to-point sectors (Alamdari, Fagan 2005), allowing a high number of daily flight frequencies in each direction (Koch 2010). By significantly reducing costs and air fares, the LCCs have successfully opened up a much broader range of point-to-point services, many not served by the full service network carriers $^{4}$ (FSNCs), and in so doing have captured at least some of the price-conscious passengers from the higherpriced FSNCs (Hunter 2006). The LCCs also do not typically operate complex aircraft rotations or itineraries. Rather the aircraft operate between their home base and their destinations (Koch 2010).

On the sales and demand side, the pricing policy of the LCCs is usually very dynamic (Doganis 2006), with heavy discounts for tickets booked long in advance, which leads to the generation of new demand from low-yield passengers who would not have flown otherwise (Ehmer et al. 2008; Vidović et al. 2013). LCCs offer single, unrestricted, and point-to-point air fares (Homsombat et al. 2014). The LCCs also focus on low-cost distribution channels (Flenskov 2005; Koch 2010) with distribution ${ }^{5}$ and sales costs being kept at a minimum by the use of internet sales, proprietary boarding control, and limited marketing budgets (Katarelos, Koufodontis 2012). Furthermore, LCCs earn ancillary revenues

\footnotetext{
${ }^{4} \mathrm{~A}$ "a full service network carrier" is an airline that focuses on the provision of a wide range of pre-flight and on-board services, including different classes of service, and connecting flights (Ehmer et al. 2008).

${ }^{5}$ LCCs typically do not rely on intermediaries such as travel agents and global distribution systems (GDS) to sell their tickets; rather they aim to sell their tickets via their website (Klophaus et al. 2012; Vidović et al. 2013).
} 
by selling other products and services both onboard the aircraft and through their websites (Doganis 2009; Francis et al. 2007). The unbundling of the traditional allinclusive airline product and the provision of unbundled low air fares can assist airlines in attracting pricesensitive passengers to their secondary airports from even greater distances away, and they are also able to compete more effectively against the full service network carriers (FSNC) for higher yielding passengers at the major airports (de Wit, Zuidberg 2012).

However, in recent times, certain features of the original LCC business model have been dropped or radically altered in response to the evolving market conditions (Alamdari, Fagan 2005). This model appears to be evolving due to the changing environment, and a new model is appearing, such as the new long-haul low cost model (Daft, Albers 2012; Morrell 2008; Wensveen, Leick 2009). "AirAsiaX" and "Jetstar Airways" are successful examples of this model.

As noted earlier, the basic LCC business model is based on low cost leadership and the core product of operating services from point A to point B (Koch 2010). LCCs concentrate on the provision of the core air transport service by omitting any costly service features and through the optimization of the entire process chain from the distribution to (ground and in-flight) operations due to their low cost structure (Klaas, Klein 2005). By having a low cost structure, LCCs are able to provide consumers with lower price services (Doganis 2006). By cutting costs to the absolute minimum, LCCs can make a profit at much lower prices than their competitors as long as pricing can stimulate demand. Lower fares create demand in two ways: by winning share of the existing travel market from customers motivated by price, and by stimulating new demand from customers who travel by bus or rail or who have never travelled before (Fernie 2011). This has led many price sensitive consumers to switch from legacy carriers to the LCCs (Flouris, Oswald 2006; Mason 2001). Moreover, the lower prices offered by LCCs have stimulated traffic between city pairs where consumers would not otherwise have flown had there not been an offer of lower fares by the LCCs (Lall 2005). This has allowed LCCs to gain a larger market share.

\section{Evolution of Australia's domestic airline market policy}

In 1949, the Australian federal government introduced a so-called "Two Airline Policy", initially by agreement but later legislated (Starkie 2008). Australia's “Two Airline Policy" became official in 1952 following the passage of the Civil Aviation Act (Mills 1989; Rhodes 2008). Under this policy only two airlines were granted access to Australia's domestic trunk routes: "Australian National Airways" (later renamed "Ansett Airlines") and the state-owned airline “Trans Australia Airlines” (TAA). In accordance with this policy the Australian government guaranteed the loans of Australian National Airways up to a set limit and later relaxed the requirement that all government employees should travel on "Trans Australia Airlines" (Rhodes 2008).

In 1957, the Australian government further declared that only two airlines would be authorized to operate on trunk routes and established a Rationalization Committee composed of a representative from each airline and a coordinator nominated by the Minister for Transport. The Airlines Equipment Act of 1958 also allowed the government to control the types of aircraft imported into the country, capacity and the entry of major operators to trunk routes (Grimm, Molloy 1993). Furthermore, during this time, the competition, coordination of scheduling and domestic passenger fares was controlled by the government (Formby et al. 1990). The airlines were not permitted to withdraw from services unless a regional airline would take their place. Restrictions, such as level and structure of air fares, capacity and regulatory barriers to entry, were designed to support services by the two airlines across the national trunk route network (May et al. 1986). In 1961, two additional acts of Parliament authorized the Rationalization Committee to establish timetables, flight frequencies, aircraft types, available capacity, air fares, air cargo rates, and overall load factors on groups of routes (Rhodes 2008).

Despite the two major incumbent airlines ("Ansett/ Trans Australia Airlines") being supposed to compete against each other, in practice, all areas where competition may have occurred were regulated, including air fares (Shaw 2011). In spite of some relaxation of the constraints within its policy, by the 1980s the policy was attracting criticism for stifling competition (Starkie 2008). Thus, in 1981, the government established the Holcroft Inquiry which recommended an air fare pricing policy based on cost that would be nationally consistent and permit discounted air fares to be set by the airlines (Rhodes 2008). Also, in 1981, the government created an Independent Air Fares Committee to appraise air fares, approve discounts, and change fare formulas to take into account cost and efficiency. This enhanced the government's ability to control capacity of regional and cargo airlines through licensing of imported aircraft (Sinha 2001). The first sign of liberalization occurred in 1981 with an amendment to the Airlines Agreement Act that enabled regional airlines to operate jet aircraft (Collins et al. 2010).

Despite the adoption of an even tougher regulatory regime, there was increasing disquiet about the Two-Airline policy. In 1985, the then Labor government appointed a committee to conduct an "Independent Review of Economic Regulation of Domestic Avi- 
ation". The committee's report was published at the end of 1986. Though the terms of reference enabled a wideranging review of the regulatory scheme to be conducted, the committee was not requested to recommend a new policy; instead it was to report on possible future policy options ${ }^{6}$ (Mills 1989).

In 1987 the Australian government announced its firm intention to remove any restrictions on entry to inter-state markets. In fact, it put the industry on three years notice. This change in policy was driven by several factors. Australia had an agenda of general deregulation during the 1980s. But, the deregulation of the United States domestic air travel market in 1979 was a further potent factor and was used as an example by those Commonwealth states that were pressing the federal government for a change in its domestic aviation policy (Starkie 2008).

On the 7th of October 1987, the Commonwealth Government gave "Ansett" and TAA the required three years notice that it would terminate the Airlines Agreement Act and deregulate the domestic airline industry. This was followed by the removal of restrictions on domestic airlines other than "Ansett" and TAA operating commercial domestic charter flights with large aircraft (Bureau... 1993). The principal features of the Australian government's new policy for interstate services were:

- Repeal of legislation: with effect in October 1990, the Australian Government will repeal the 1981 legislation that regulates capacity, route entry, and air fares.

- Foreign ownership provisions: any foreign international airline operating services to Australia will not be permitted to hold more than 15 per cent equity in any airline providing domestic services. Otherwise foreign firms may invest in Australian airline companies, subject to the normal guidelines of the Foreign Investment Review Board.

- Consumer protection: airlines will become subject to all provisions of the Trade Practices Act; and air fares will be subject to scrutiny by the Prices Surveillance Authority (PSA), though the requirement for continued involvement of the PSA will be reviewed following an interim period of three years; and

- Domestic rights for Qantas: with effect from 1 July 1988, Qantas was granted the right to carry, on its domestic sectors, passengers of other international airlines (in addition to its right to carry its own international passengers) (Mills 1989).

\footnotetext{
${ }^{6}$ See G. Mills (1989: 210-211) for a summary of the committee's key findings and suggested policy options.
}

On November 1, 1990, the entire industry was deregulated ending the "Two Airline Policy" at the federal level. The Airlines Agreement Act (1981) (Cth) s3, as well as the 1981 Airlines Agreement between the Commonwealth and the two major incumbent carriers was terminated. In 1990, the Commonwealth also withdrew from the application of passenger capacity provisions in the Airline Equipment Acts (1958-1981) (Cth). Also, in 1990, the Commonwealth announced its decision to privatise "Australian Airlines" (formerly TAA). The control of air fares through the Independent Air Fares Committee was also abolished with the disbandment of the commission (Moens, Gillies 2000). However, some state governments maintained economic regulation of intra-state routes, while at the national level, the Australian Competition and Consumer Commission (ACCC) monitors the state of competition in the industry in accordance with its generic competition responsibilities (Kain, Webb 2003). The regulations of competition, route entry and capacity were terminated. New domestic airlines were permitted on all domestic routes (Collins et al. 2010; Forsyth 2003). Also, the constraints for domestic airlines were removed, which included: aircraft imports control, capacity and supply control on trunk routes by each airline, entry and exit barriers to domestic trunk routes and abolition of the Independent Airfares Committee in setting fare levels (Bureau... 1991).

In September 1992 "Qantas Airways" acquired "Australian Airlines" (Moens, Gillies 2000; Quinlin 1998). The merged "Qantas-Australian Airlines" were partly privatised in 1993, a process completed in 1995 (Kong 1999). A major event in Australia's domestic airline market in 2001, however, was the collapse of Ansett Australia (Forsyth 2003; Prideaux 2003).

Figure 1 shows the annual growth in Australia's domestic enplaned passengers and revenue passenger kilometres performed ${ }^{7}$ (RPKs) from 1944 to 2013.

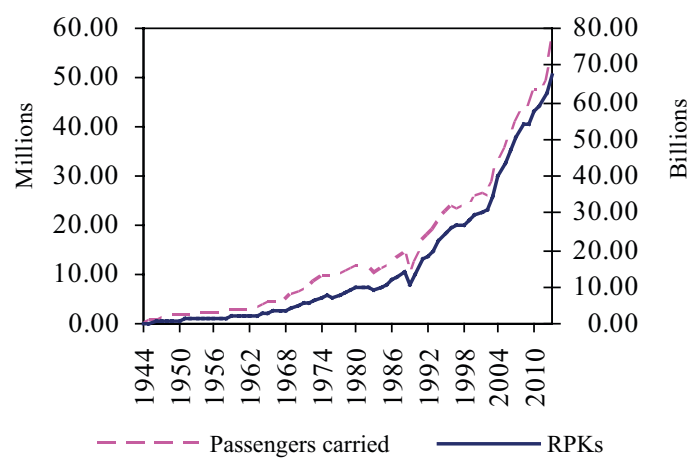

Fig. 1. Development of Australia's annual enplaned domestic passengers and revenue passenger kilometres performed (RPKs): 1944-2013 (Bureau... 2014)

\footnotetext{
${ }^{7}$ Revenue passenger kilometres (RPKs) are obtained by multiplying the number of fare paying passengers on each flight stage by the flight stage distance (Doganis 2009: 327).
} 


\section{Emergence of low cost carriers in Australia's domestic airline market}

The development of LCCs commenced in Australia in 1990 along with the deregulation of Australia's domestic air travel market (Homsombat et al. 2014). As noted earlier, the market was dominated by two incumbent airlines: "Qantas" and "Ansett Australia". The deregulation opened the market and enabled new entrants to compete on all domestic routes (Forsyth 1998).

In December 1990, quite soon after Australia's domestic market was deregulated, "Compass Airlines" was the first new entrant to the market (Quiggin 1997). "Compass Airlines" strategy was to compete as an LCC in Australia's domestic airline market. The airline operated a single aircraft type, the 266 seat "Airbus A300-600" aircraft. The airline route network structure was quite simple, linking up seven major airports (Collins et al. 2010). At one point in time, "Compass" had captured 10 per cent of the total domestic market and up to 21 per cent on the routes that the airline served (Bureau... 1991). However, "Compass" experienced problems in gaining access to airport slots and suffered from aircraft delivery delays (Grimm, Molloy 1993). Furthermore, "Ansett" and "Qantas", the two incumbent airlines, met "Compass Airlines" entry into the market with strong capacity increases and this contributed to the airline's amounting debt (Koo 2009). "Compass" lasted for about a year, when its funds were exhausted following a vigorous price war (Nyathi et al. 1993a, b).

In 1992, not long after "Compass" had collapsed, a second airline, by now called “Compass Mark II”, entered the Australian domestic market (Forsyth 2003). This airline operated for about six months when it too failed (Hooper 1998). P. Forsyth (2003) observed that although there were a number of favourable factors facilitating LCC services, for instance, a number of dense routes and some leisure markets within Australia's domestic market, these were essentially offset by strong head-on competition with the incumbents, financial and marketing issues, and insufficient accessibility (Homsombat et al. 2014). From 1994-1999 a duopoly compromising "Ansett" and "Qantas" emerged in Australia's domestic airline market (Koo 2009). No LCCs operated in Australia's domestic market for the remainder of the decade (Collins et al. 2010).

The second phase of LCC entry commenced in 2000, with the formation of "Impulse Airlines" and "Virgin Blue" (Homsombat et al. 2014; Koo 2009). Impulse was a successful Australian regional airline with a healthy financial status; it had no outstanding debts and a consistent record of profit margins. Impulse was based in New South Wales, operated a low price, single class service on major competitive trunk routes, Brisbane-Melbourne-Sydney with five "Boeing 717-200" aircraft. Impulse aimed to provide a friendly, cheerful, hospitable, no-nonsense country style service (Killian 2001). Moreover, it selected highly competitive routes when it confronted the major incumbent airlines, a strategy usually avoided by new start-up low cost carriers (Lawton 2002). Furthermore, its fares were no-conditions, fully flexible and fifty percent lower than "Ansett" and "Qantas" (Forsyth 2003). By early 2001, "Impulse" was experiencing liquidity problems, and by April 2001 Impulse was leasing its aircraft to "Qantas" (Collins et al. 2010). With this agreement Impulse would operate services for "Qanta" under the "Qantas" brand and would terminate its major trunk routes (Forsyth 2003). "Qantas" acquired "Impulse" in November 2001 (Collins et al. 2010).

Shortly after "Impulse" entered the market, "Virgin Blue Airlines" was established. "Virgin Blue" commenced operations in Australia in August 2000 with two "Boeing B737" aircraft operating 7 flights per day between Brisbane and Sydney (Thomas 2006a). Its original owner and founder was a British businessman, Sir Richard Branson (Thomas 2000). Two important features in the second phase of LCCs' entry into the market contributed to Virgin Blue's success. First, "Ansett Australia" ceased operations in September 2001 leaving a very significant capacity shortfall in Australia (Forsyth 2003; Koo 2009). The sudden drop in domestic seat capacity following "Ansett's" collapse assisted "Virgin Blue" to expand rapidly with a competitive LCC business model (Collins et al. 2010). Secondly, "Virgin Blue" was in a much more favourable position than its predecessors ("Compass I" and "Compass II") being part of an international conglomerate, the "Virgin Group" (Forsyth 2003). In addition, the old airport terminal space previously occupied by "Ansett" was also easily acquired at most airports (Collins et al. 2010). However, the airline sought investors to inject capital in the new airline following the collapse of "Ansett Australia" in September 2001. The "Patrick Corporation" purchased a 50 per cent stake in "Virgin Blue" in 2002 (Thomas 2006a). The airline was publicly listed on the Sydney Stock Exchange in 2003 (Thomas 2003, 2006a).

"Toll Holdings" bought control of "Virgin Blue" in 2006 (Knibb 2008b). However, in July 2008, “Toll Holdings" decided to transfer its 62.7 per cent stake in "Virgin Blue" to the company's other shareholders. At this time the "Virgin Group" was the largest single shareholder with a 25.5 per cent stake in the company (Knibb 2008a). In 2004, the airline launched its New Zealand leisure based airline, Pacific "Blue", which operated internationally, between Australia, New Zealand, the Cook Islands, Fiji, Tonga and Vanuatu. In 2005, "Virgin Blue" launched a joint venture with the Government of Samoa to launch Polynesian Blue (Knibb 2005). 
In March 2007, "Virgin Blue" confirmed that they would launch V-Australia, an international airline which would serve leisure travellers between Australia and the United States. To operate this network, V-Australia signed a deal with "Boeing" for six 777-300ER aircraft (Knibb 2007d). The new airline commenced services on the 28th February 2009 when it commenced operations from Sydney to Los Angeles (Moores 2009). V-Australia was established as a part of "Virgin Blue's" strategy of expanding its range of services to include long-haul international markets, such as the USA (Ionides 2008).

In 2005, "Virgin Blue" started to reposition itself as a "New World Carrier", following the introduction of "Jetstar" by "Qantas", and also to enable it to compete against both "Qantas" and "Jetstar" in the Australian domestic market better (Centre for Aviation 2010). Under this strategy, the airline introduced various services that LCCs normally avoided. In April 2003, the airline opened airport lounges and this was followed by the introduction of a frequent flyer programme in November 2005 (Collins et al. 2010). In 2008, "Virgin Blue" introduced a premium economy class in order to attract higher yield business traffic (Collins et al. 2010; Knibb 2007c).

"Virgin Blue" has expanded its route network beyond linking Australia's capital cities and beyond the traditional tourist routes that link larger coastal tourist destinations, for example, Cairns and Townsville, with the capital cities. The airline's route network strategy has included the addition of routes that were previously only served by regional carriers, for example, Melbourne to Mildura (Collins et al. 2010). In order to ensure that these thin routes would be economically viable, "Virgin" acquired a fleet of 24 "Embraer E-170" and E-190 regional jets, which carry 76 and 104 passengers, respectively (Collins et al. 2010). The airline also used the "Embraer" jets to boost flight frequencies on key business routes (Virgin... 2006b). In 2011, "Virgin Blue" announced that it was disposing its fleet of smaller, "Embraer E-170" aircraft (Dorman 2011) and replacing them with a fleet of ATR 72 regional turboprop aircraft that will be operated under its strategic alliance with "Skywest Airlines" (Australian Aviation 2011).

On the 7th December 2011, the "Virgin Australia" group of airlines officially launched its international airlines V-Australia and "Pacific Blue" under the new brand, "Virgin Australia". On the same day, the "Virgin Australia" group of airlines also unveiled a new brand and livery for its joint venture with the Government of Samoa, "Polynesian Blue", announcing that the country's national airline would operate as "Virgin Samoa" (Virgin Blue 2011b).

"Virgin Blue" turned out to be the only "native" independent LCC that survived in Australia's domestic air travel market (Homsombat et al. 2014). The airline ad- opted a somewhat different business model compared to previous LCCs. For instance, it offered customers connecting services, engaged in code-sharing agreements with major airlines, and was able to sustain airfares significantly lower than those of "Qantas" (Francis et al. 2006). Most importantly, the collapse of "Ansett Australia" in 2001 greatly benefited "Virgin Blue". The markets previously served by "Ansett Australia", which accounted for in excess of 40 per cent of Australia's domestic air travel market, were largely acquired by both "Virgin Australia" and "Qantas" (Homsombat et al. 2014). This enabled "Virgin Blue" to capture in excess of 30 per cent of Australia's domestic air travel market as of early 2003 (Easdown, Wilms 2002).

In response to "Virgin Australia's" success and aggressive growth, "Qantas" established "Jetstar Airways" in 2003, a similar strategy to those implemented by full service network carriers in North America and Europe (Homsombat et al. 2014). "Jetstar" is a wholly owned subsidiary of the "Qantas Group", with "Jetstar Airways" low fare operations commencing in May 2004 (Collins et al. 2010; Jetstar Airways 2013). "Jetstar" began operations with a fleet of 14 "Boeing 717" aircraft that "Qantas" inherited from its acquisition of "Impulse Airlines” (Knibb 2004a), providing 800 flights a week to 14 destinations around Australia. The airline also decided to operate flights to and from Avalon Airport (an airport located around 55 kilometres from Melbourne) (Thomas 2007), thus becoming the first Australian carrier to operate from a "secondary city" airport (Qantas Airways 2004).

During 2004, the "Qantas Group” decided to move "Jetstar" into a standardized fleet of 177 seat "Airbus A320" aircraft (Knibb 2004b). These aircraft provided significant fuel and technology efficiencies and were therefore ideal for "Jetstar's" short haul operations. The airline's original fleet of "Boeing 717" aircraft were transferred to QantasLink, a regional airline subsidiary of the "Qantas Group" (Qantas Airways 2004). "Jetstar International" was due to receive the first of a fleet of at least 15 "Boeing 787" aircraft in August 2008 (Francis, Knibb 2008). The airline now operates a fleet comprising 57 "Airbus A320", 6 “Airbus A321", 7 "Airbus A330200" and 3 "Boeing B787-8" aircraft (Jetstar Airways 2013).

Initially "Jetstar" was positioned to tap into the leisure travel market and its services originally focused on linking Australia's capital cities with leisure destinations. As the airline grew, its strategic emphasis shifted to linking up Australia's major population centres (Thomas 2007). The airline later expanded to include international services, commencing services from Brisbane, Gold Coast, Melbourne and Sydney to Christchurch, New Zealand, in December 2005 (Thomas 2007). 
In 2006, "Qantas" decided to launch a low-cost international division, "Jetstar International"8. Providing a two class service, the services were targeted at the market between single-class low cost and the traditional two-orthree class international carrier services. "Jetstar's" international services involved initial stage lengths of between 6 to 10 hours to key Asian and Pacific leisure destinations (Knibb 2006). Following a year of preparatory work, "Jetstar International" launched long-haul international services in November 2006 with wide-body "Airbus A330" services to Bangkok and Phuket in Thailand, followed by services to Ho Chi Minh City in Vietnam and Denpasar, Bali (Ionides 2007b). Services to Honolulu and Osaka in Japan commenced in 2007 as well. "Jetstar" now operates services to 19 Australian domestic destinations and 17 short and long haul international destinations (Jetstar Airways 2013).

Figure 2 shows the annual growth in Australian domestic passengers carried by "Jetstar" and the concomitant RPKs performed from 2004/05 to 2012/13.

Singapore-based “Tiger Airways" launched "Tiger Airways Australia” in 2007 (Thomas 2006b). “Tiger Airways Australian" carrier had the same shareholders as the main Singapore-based airline, which meant that the carrier was entirely foreign owned - something that was permissible under Australia's liberal domestic airline ownership regime which permits foreign ownership of a domestic airline (Ionides 2007a; Knibb 2007a). “Tiger Airways", which was based at Melbourne's Tullamarine Airport, commenced operations with low-cost services to Perth and Darwin, operating a fleet of 5 "Airbus A320" aircraft (Koo 2009). Despite their small fleet, "Tiger Airways" had an impact on Australia's incumbent LCC, "Jetstar", by forcing it to operate services on the same routes as "Tiger", as well as providing connecting services to/from Melbourne Airport, a strategy that Jetstar had previously avoided preferring to operate from Melbourne's secondary airport, Avalon (Koo 2009). “Tiger Airways” arrival into Australia's domestic market also prompted a change to the "Qantas" long-standing policy as to where "Jetstar" operated. Prior to 2007, "Jetstar" avoided operating on routes served by "Qantas". In anticipation of "Tiger's" entry into the market, "Qantas" made a significant change to this policy by allowing "Jetstar" to compete on the same Sydney-Brisbane route served by "Qantas". Prior to this change, the heavily travelled Sydney-Melbourne-Brisbane triangle was served exclusively by "Qantas" City Flyer Service and by rival "Virgin Blue". The bulk of Australia's

\footnotetext{
$\overline{8}$ Qantas launched Singapore-based "Jetstar Asia" in 2004, with management rights and with a 44.5 per cent equity stake (Knibb 2007b). "Jetstar Asia" commenced operations on the 13th December 2005 with services from Singapore to Hong Kong (Ionides 2005). In 2007, "Qantas" acquired an 18 per cent stake in Vietnam's "Pacific Airlines". "Pacific Airlines" took the "Jetstar" name, and converted its fleet from "Boeing B737s" to "Airbus A320s" - the same aircraft used by "Jetstar" and "Jetstar Asia” (Knibb 2007b; Sobie 2009).
}

domestic business travel occurs in this triangle (Knibb 2007e). "Tiger Airways" currently serves Adelaide, Alice Springs, Brisbane, Cairns, Coffs Harbour, Darwin, Gold Coast, Hobart, Mackay, Melbourne, Proserpine, Sunshine Coast and Sydney (Tiger Airways 2014).

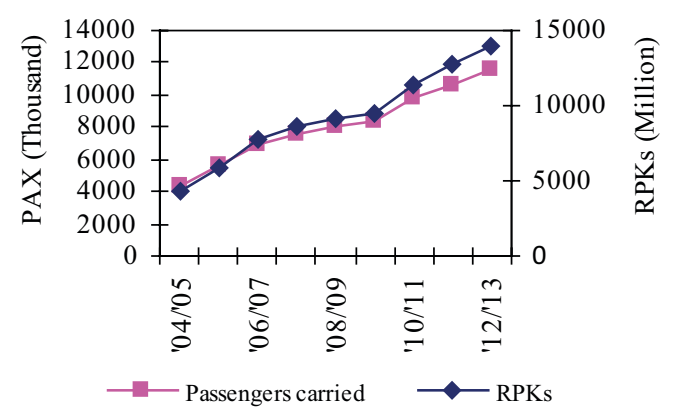

Fig. 2. Development of "Jetstar Australia's" annual enplaned domestic passengers and revenue passenger kilometres (RPKs): 2004/2005 - 2012/2013 (Qantas Airways (various))

In November 2011, a new budget carrier flying passengers both domestically and to key regional tourist markets was launched. Previously a charter business, "Strategic Airlines" rebranded itself as "Air Australia" (Nancarrow 2011). However, in February 2012, "Air Australia" ceased operations and was placed into voluntary administration (Ironside 2012; Ryan 2012).

Driven by the strong growth of "Virgin Blue" and "Jetstar", Australia's low cost air travel market sector has been growing rapidly in recent years. As figure 3 illustrates, the LCCs' market share grew sharply in 2001/2002 following the entry of "Virgin Blue" into the market. Such growth momentum was sustained following the entry of "Jetstar" in 2003 and has more or less stabilized since 2005, when the LCCs collectively had captured more than 50 per cent of the total market (Fig. 3). The LCCs' share of Australia's domestic airline (annual enplaned passengers) peaked in 2010 , with a 64 per cent market share. However, over the past 3 years, the LCCs' market share has declined to around 31 per cent, primarily due to the change in the "Virgin Australia's" strategy to adopt a full service network carrier (FSNC) business model.

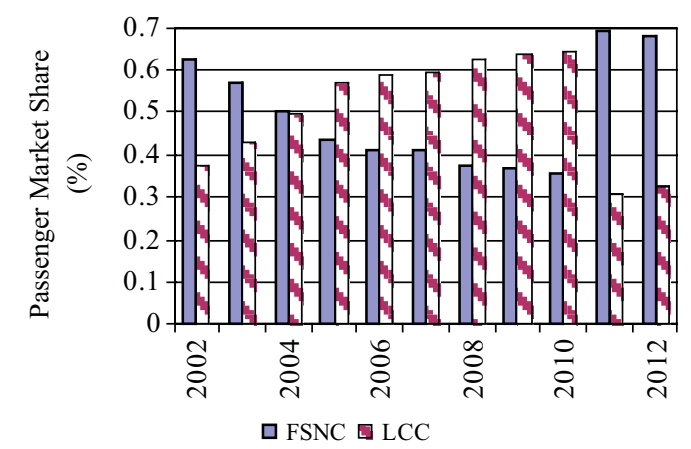

Fig. 3. Full service network and lower cost carrier annual enplaned passenger market share: 2002-2013 (Bureau... 2014; Qantas Airways 2009, 2013; Tiger Airways (various); Virgin Australia (various) 
Figure 4 shows the growth in the LCCs' Australian domestic market share as measured by revenue passenger kilometres (RPKs), from 2001/2002 to 2012/2013 and highlights a strong growth in RPKs from 2005 to 2010, when the LCCs' share peaked at around 50 per cent. From 2011 to 2013 the decline in the LCCs' annual RPKs was principally due to the change in "Virgin Australia's" strategy when moving from an LCC to a full service network carrier business model.

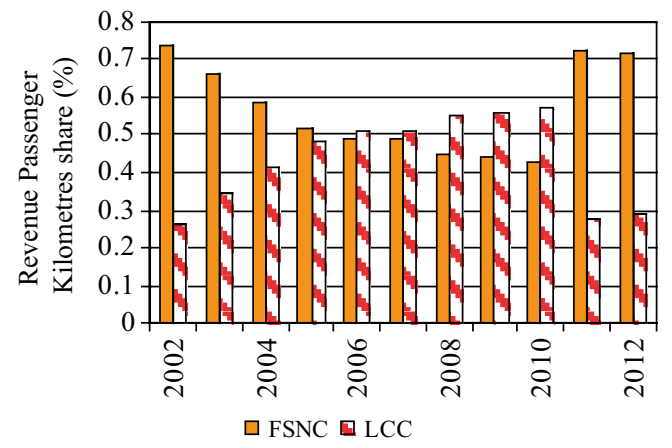

Fig. 4. Full service network and lower cost carrier annual revenue passenger kilometres (RPKs) market share: 2002-2013 (Bureau... 2014); Qantas Airways 2009, 2013; Tiger Airways (various), Virgin Australia (various))

Another significant change that occurred in the third phase of Australia's domestic airline market has been the evolution of the two incumbent airlines: "Jetstar" and "Virgin Australia" (previously called "Virgin Blue") (Koo 2009). In recent years, "Virgin Australia" has increasingly focused on becoming a full service network carrier (FSNC) similar to "Qantas" (Koo 2009). "Virgin Australia's" business model is focussing on the expansion into smaller regional markets with lower levels of demand (markets being served by medium size "Embraer" aircraft); increasing use of a hub-and-spoke network strategy; the introduction of business lounges and premium seating classes; code-sharing and/or interlining arrangements with domestic (for example, REX Express) and international airlines, such as "Air New Zealand", "Delta Airlines", "Etihad" and "Hawaiian Airlines"), and a mixed fleet, including long-haul "Boeing 777" aircraft used to operate services to the USA (Knibb 2008a; Koo 2009). In December 2012, "Virgin Australia" announced plans to match the "Qantas" portfolio of domestic airlines by acquiring 60 per cent of "Tiger Airways Australia" and all of Perth, Western Australia-based "Skywest Airlines". Under this strategy "Tiger Airways" would compete on "Virgin's" behalf against "Qantas" LCC unit "Jetstar", whilst "Skywest" would compete against QantasLink on regional and mining-related routes. In order to fund these acquisitions, and the cost of enhancing these airline operations, "Virgin" sold a ten per cent stake in itself to "Singapore Airlines". This ambitious initiative formed part of "Virgin Australia's' re-branding strategy, designed to distance itself from the low-cost carrier sector and compete more with mainline "Qantas" in the premium business market (Knibb 2012).

"Virgin Australia's" strategic repositioning continues to attract shareholder interest with "Singapore Airlines" strengthening its cooperation and equity investment in the carrier. Together with the 10 per cent shareholding acquired in November 2012, "Singapore Airlines" now holds a 19.9 per cent stake in "Virgin Australia" (Taylor 2013). On June 17, 2014, "Air New Zealand" increased its shareholding in "Virgin Australia" to 25.9 per cent. "Etihad Airways" and "Singapore Airlines" also held stakes of 21.24 per cent and 33.27 per cent at that time, respectively (Freed 2014). Figure 5 shows the annual growth in Australian domestic passengers carried and revenue passenger kilometres (RPKs) performed by "Virgin Australia" from 2002 to 2013.

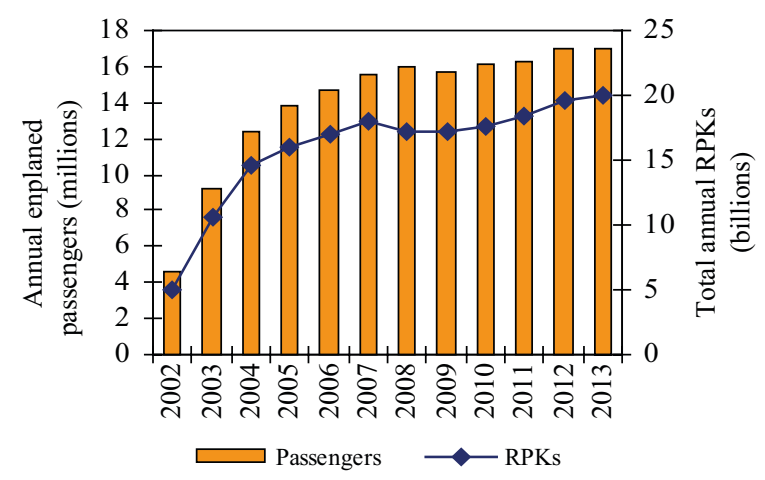

Fig. 5. Development of "Virgin Australia" domestic passengers and revenue passenger kilometres (RPKs): 2002-2013. Note: 2002 data for 9 months ("Virgin Australia", "Virgin Blue" (various annual reports))

Currently, two LCCs dominate Australia's domestic air travel market: "Jetstar Airways" and "Tiger Airways". "Jetstar Airways" now forms an integral part of the "Qantas Group's" two-brand strategy, operating in the leisure and value-based market segments (Jetstar Airways 2013). The dual "Qantas Group" brand strategy has resulted in the group capturing a significant market share (Homsombat et al. 2014).

\section{Conclusions}

The emergence of low cost carriers has become a global phenomenon, with virtually all travel markets containing at least some low cost carriers today (Vasigh et al. 2008). This paper has examined the evolution of LCCs in Australia's domestic air travel market and has shown that since the market was deregulated on the 30th October 1990, the LCC market has had three discrete phases. The first wave of LCCs entered the market between 1990 and 1993. During this phase, several LCCs - "Compass" and 
“Compass Mark II" - commenced business, but both subsequently failed within a year of starting operations. During the period from 1994-1999, a duopoly encompassing "Ansett Airlines" and "Qantas" emerged in Australia's domestic air travel market (Koo 2009).

The second wave of LCCs with "Impulse Airlines" and "Virgin Blue" entering the market occurred between 2000 and 2006. "Impulse Airlines" was initially a regional airline, but later decided to expand its operations and compete against "Ansett" and "Qantas" on domestic trunk routes. Impulse, similar to its predecessor, also collapsed, and was acquired by "Qantas” in November 2001. "Virgin Blue", the first successful in Australia, was a major beneficiary of the collapse of "Ansett Australia" in 2001. The collapse of "Ansett Australia" provided "Virgin Blue" with the opportunity to capture a very large capacity gap. In addition, "Virgin Blue" was in a stronger financial position than the earlier LCCs - "Compass", "Compass Mark II" and "Impulse Airlines" - being part of the "Virgin Group". The strategic focus of "Virgin Blue" changed during this period with the airline seeking to become a "New World Carrier". Under this strategy, the airline introduced airport lounges, a premium economy product, and a frequent flyer program, product attributes that LCCs have normally eschewed (Collins et al. 2010).

The third phase in the evolution of Australia's domestic LCC air travel market occurred in the post-2006 period. In 2007, Singapore-based “Tiger Airways” established "Tiger Airways Australia”, with a small fleet of "Airbus A320" aircraft. "Tiger Airways" currently operates services to 13 destinations around Australia, which include the major capital cities as well as key tourist centres. Another significant change in Australia's domestic LCC air travel market that has signified a third wave has been the evolution of two incumbent LCCs "Jetstar" and "Virgin Australia". Since 2011, "Virgin Australia" has changed from an LCC to a full service network carrier business model, similar to that of "Qantas". The change in "Virgin Australia's" strategic focus, and business model, is evident due to its expansion into smaller regional markets with lower levels of demand, growing use of a hub-and-spoke route network strategy, introduction of airport business lounges and premium seating classes, operation of a mixed aircraft fleet, including long haul "Boeing B777-300ER" aircraft, and the extension of its marketable network through code-sharing and/or interline agreements with key domestic and international partner airlines. A further feature of the third phase of the evolution Australia's LCCs has been the focus of the incumbents on establishing long-haul international operations. "Jetstar International", was launched in 2007, with long-haul, low-cost services from Australia to Honolulu, Hawaii, Japan and Thailand.
The LCCs' market share grew sharply in 2002 following the entry of "Virgin Blue". The LCCs' share of Australia's domestic airline (annual enplaned passengers) peaked in 2010, with a 64 per cent market share. However, over the past 3 years, the LCCs' market share has dropped to around 31 per cent, primarily due to the change in the "Virgin Australia" strategy to adopt a full service network carrier business model.

\section{References}

Alamdari, F.; Fagan, S. 2005. Impact of the adherence to the original low cost model on the profitability of low cost airlines, Transport Reviews 25(3): 377-392. http://dx.doi.org/10.1080/01441640500038748

Australian Aviation. 2011. Virgin Blue Chooses ATR, Australianaviation.com.au. February 23 [online], [cited 8 May 2014]. Available from Internet: http://australianaviation. com.au/2011/02/virgin-blue-chooses-atr-reveals-somea330-cabin-details

Baker, D.; Donnet, T. 2012. Regional and remote airports under stress in Australia, Research in Transportation Business \& Management 4(October): 37-43.

http://dx.doi.org/10.1016/j.rtbm.2012.06.011

Barbot, C. 2006. Low-cost airlines, secondary airports, and state aid: an economic assessment of the Ryanair-Charleroi Airport agreement, Journal of Air Transport Management 12(4): 197-203. http://dx.doi.org/10.1016/j.jairtraman.2006.04.001

Barrett, S. D. 2004. The sustainability of the Ryanair model, International Journal of Transport Management 2(2): 89-98. http://dx.doi.org/10.1016/j.ijtm.2004.12.001

Bieger, T.; Agosti, S. 2005. Business models in the airline sector - evolution and perspectives, in W. Delfmann, H. Baum, S. Auerbach, et al. (Eds.). Strategic Management in the Aviation Industry. Aldershot, UK: Ashgate Publishing, 41-64.

Bureau of Transport and Communication Economics. 1991. Deregulation of Domestic Aviation: The First Year. Report 73. Canberra: Australian Government Publishing Service.

Bureau of Transport and Communication Economics. 1993. The Progress of Aviation Reform. Report 81. Canberra: Australian Government Publishing Service.

Bureau of Infrastructure, Transport and Regional Economics. 2014. Domestic Aviation Industry Annual Summaries 1984-85 to 2012-13 and 1984 to 2013 [online], [cited 28 April 2014]. Available from Internet: https:// www.bitre. gov.au/publications/ongoing/domestic_airline_activity-time_series.aspx

Centre for Aviation. 2010. Virgin Blue - has its "New World Carrier" Experiment Been a Success? [online], [cited 3 May 2014]. Available from Internet: http://centreforaviation. com/analysis/virgin-blue--has-its-new-world-carrier-experiment-been-a-success-18017

Chang, L. Y.; Hung, S. C. 2013. Adoption and loyalty towards low cost carriers: the case of Taipei-Singapore passengers, Transportation Research. Part E 50 (February): 29-36. http://dx.doi.org/10.1016/j.tre.2012.10.003

Collins, A.; Hensher, D. A.; Li, Z. 2010. Regional airports and opportunities for low-cost carriers in Australia, in M. N. Postorino (Ed.). Development of Regional Airports: Theoretical Analyses and Case Studies. Southampton: WIT Press, 149-174. 
http://dx.doi.org/10.2495/978-1-84564-143-6/07

Daft, J.; Albers, S. 2012. A profitability analysis of low-cost long-haul flight operations, Journal of Air Transport Management 19(March): 197-203.

Daraban, B. 2012. The low cost carrier revolution continues: evidence from the US airline industry, Journal of Business \& Economics Research 10(1): 37-44.

de Neufville, R. 2006. Planning airport access in an era of lowcost airlines, Journal of the American Planning Association 72(3): 347-356. http://dx.doi.org/10.1080/01944360608976756

de Neufville, R. 2008. Low-cost airports for low-cost airlines: flexible design to manage the risk, Transportation Planning and Technology 31(1): 35-68. http://dx.doi.org/10.1080/03081060701835688

de Wit, J. G.; Zuidberg, J. 2012. The growth limits of the low cost carrier model, Journal of Air Transport Management 21(July): 17-23.

http://dx.doi.org/10.1016/j.jairtraman.2011.12.013

Doganis, R. 2006. The Airline Business. 2nd ed. Abingdon, UK: Routledge.

Doganis, R. 2009. Flying off Course: Airline Economics and Marketing. 4th ed. London: Routledge.

Dorman, C. 2011. Virgin Blue ditches jets to go 'retro', in The Sydney Morning Herald, January 31 [online], [cited 8 May 2014]. Available from Internet: http://www.smh.com.au/ travel/blogs/travellers-check/virgin-blue-ditches-jets-togo-retro-20110131-1aabi.html

Easdown, G.; Wilms, P. 2002. Ansett the Collapse. Melbourne: Lothian Books.

Ehmer, H.; Berster, P.; Bischoff, G., et al. 2008. Analyses of the European Air Transport Market - Airline Business Models. Report 1.01. Köln: Deutsches Zentrum für Luft- und Raumfahrt e.v (DLR).

Fernie, A. 2011. AERO2322 Airline Marketing Learning Guide Topic 1 - Strategic Planning. Melbourne, Australia: RMIT University.

Flenskov, K. 2005. From production-orientation to customer-orientation - modules of a successful airline differentiation strategy, in W. Delfmann, H. Baum, S. Auerbach, et al. (Eds.). Strategic Management in the Aviation Industry. Aldershot, UK: Ashgate Publishing, 97-117.

Flouris, T. G.; Oswald, S. L. 2006. Designing and Executing Strategy in Aviation Management. Aldershot, UK: Ashgate Publishing.

Formby, J.; Thistle, P.; Keeler, J. 1990. Cost under regulation and deregulation: the case of the United States passenger airlines, Economic Record 66(4): 308-321. http://dx.doi.org/10.1111/j.1475-4932.1990.tb01736.x

Forsyth, P. 1998. Airline deregulation in Australia: a medium term assessment, in Air Transport Research Group Conference, July 1998, Dublin, Ireland.

Forsyth, P. 2003. Low-cost carriers in Australia: experiences and impacts, Journal of Air Transport Management 9(5): $277-284$. http://dx.doi.org/10.1016/S0969-6997(03)00035-8

Francis, G.; Dennis, N.; Ison, S., et al. 2007. The transferability of the low-cost model to long haul operations, Tourism Management 28(2): 391-398. http://dx.doi.org/10.1016/j.tourman.2006.04.014

Francis, G.; Humphreys, I.; Ison, S., et al. 2006. Where next for low cost airlines? A spatial and temporal comparative study, Journal of Air Transport Geography 14(2): 83-94. http://dx.doi.org/10.1016/j.jtrangeo.2005.05.005
Francis, L.; Knibb, D. 2008. Jetstar shifts focus, Airline Business 24(3): 23.

Freed, J. 2014. Air New Zealand ups stake in Virgin Australia, in Sydney Morning Herald, June 17 [online], [cited 14 July 2014]. Available from Internet: http://www.smh.com.au/ business/aviation/air-new-zealand-ups-stake-in-virginaustralia-20140617-3a9j3.html

Gillen, D.; Lall, A. 2004. Competitive advantage of low cost carriers: some implications for airports, Journal of Air Transport Management 10(1): 41-50. http://dx.doi.org/10.1016/j.jairtraman.2003.10.009

Goh, M. 2005. Low cost carriers in Southeast Asia: a preliminary analysis, in W. Delfmann, H. Baum, S. Auerbach, et al. (Eds.). Strategic Management in the Aviation Industry. Aldershot, UK: Ashgate Publishing, 143-163.

Grimm, C. M.; Molloy, H. B. 1993. Australian domestic aviation deregulation: impacts and implications, Logistics and Transportation Review 29(3): 259-273.

Homsombat, W.; Lei, Z.; Fu, X. 2014. Competitive effects of the airlines-within-airlines strategy: pricing and route entry patterns, Transportation Research. Part E. 63(March): 1-16. http://dx.doi.org/10.1016/j.tre.2013.12.008

Hooper, P. 1998. Airline competition and deregulation in developed and developing country contexts - Australia and India, Journal of Transport Geography 6(2): 105-116. http://dx.doi.org/10.1016/S0966-6923(98)00004-0

Hunter, L. 2006. Low cost airlines: business model and employment relations, European Management Journal 24(5): 315-321. http://dx.doi.org/10.1016/j.emj.2006.08.001

Ionides, N. 2005. Jetstar Asia stretches out, Airline Business 21(1): 30 .

Ionides, N. 2007a. Attention seeker, Airline Business 23(6): 33-36.

Ionides, N. 2007b. Jetstar launches long-haul services, Airline Business 23(1): 23.

Ionides, N. 2008. Australian carriers held up, Airline Business 24(11): 44.

Ironside, R. 2012. Budget airline Air Australia placed in administration, in The Courier-Mail, 17 February [online], [cited 29 March 2014]. Available from Internet: http:// www.couriermail.com.au/news/queensland/budget-airline-air-australia-placed-in-administration/storye6freoof-1226273391831

Jetstar Airways. 2013. About Us: Our Company [online], [cited 23 March 2014]. Available from Internet: http://www.jetstar.com/au/en/about-us/our-company

Kain, J.; Webb, R. 2003. Turbulent Times: Australian Airline Industry. Canberra: Information and Research Services, Department of the Parliamentary Library.

Katarelos, E.; Koufodontis, I. 2012. Business relations between the low cost carriers and airports as a consequence of the air transport deregulation, Journal of Air Transport Studies 3(1): 57-77.

Kazda, A.; Caves, R. E. 2007. Airport Design and Operation. 2nd ed. Jordon Hill, UK: Elsevier.

Killian, M. 2001. The twin-engine Cockatoo, Airliner World 8.

Klaas, T.; Klein, J. 2005. Strategic airline positioning in the German low cost carrier (LCC) market, in W. Delfmann, H. Baum, S. Auerbach, et al. (Eds.). Strategic Management in the Aviation Industry. Aldershot, UK: Ashgate Publishing, 119-142.

Klophaus, R.; Conrady, R.; Fichert, F. 2012. Low cost carriers going hybrid: evidence from Europe, Journal of Air Transport Management 23(August): 54-58.

http://dx.doi.org/10.1016/j.jairtraman.2012.01.015 
Knibb, D. 2004a. Jetstar takes shape for May start, Airline Business 20(1): 21.

Knibb, D. 2004b. Virgin Blue makes an early attack on start-up Jetstar, Airline Business 20(2): 22.

Knibb, D. 2005. Virgin Blue seeks home for cheap 737s, Airline Business 21(9): 30.

Knibb, D. 2006. JetStar moves onto the international stage, Airline Business 22(1): 21.

Knibb, D. 2007a. Attention seeker, Airline Business 23(6): 33-36.

Knibb, D. 2007b. Bridge building, Airline Business 23(9): 80-83.

Knibb, D. 2007c. Reinvention time in Australia, Airline Business 23(9): 28.

Knibb, D. 2007d. The winner is...V-Australia, Airline Business 23(9): 32.

Knibb, D. 2007e. Tiger prompts Jetstar rule change, Airline Business 23(8): 30.

Knibb, D. 2008a. Silver lining, Airline Business 24(9): 54-55.

Knibb, D. 2008b. Toll seeks to reduce Virgin stake, Airline Business 24(4): 28.

Knibb, D. 2012. Will three into two go in Australia?, Airline Business 28(12): 14.

Koch, B. 2010. Aviation strategy and business models, in A. Wald, C. Fay, R. Gleich (Eds.). Introduction to Aviation Management. Münster, Germany: LIT Verlag, 143-184.

Kong, L. 1999. The geography of air transport in Austral-Asia: a global perspective, Australian Geographical Studies 37(2): 105-113. http://dx.doi.org/10.1111/1467-8470.00072

Koo, T. T. R. 2009. The effects of low-cost carriers on regional dispersion of domestic visitors in Australia: Unpublished $\mathrm{PhD}$ thesis. University of New South Wales, Sydney, NSW, Australia.

Kua, J.; Baum, T. 2004. Perspectives on the development of low-cost airlines in South-east Asia, Current Issues in Tourism 7(3): 262-276. http://dx.doi.org/10.1080/13683500408667982

Lall, A. 2005. Predatory pricing: still a rare occurrence?, in P. Forysth, D. W. Gillen, O. G. Mayer, et al. (Eds.). Competition Versus Predation in Aviation Markets: a Survey of Experience in North America, Europe and Australia. Aldershot, UK: Ashgate Publishing, 37-56.

Lawton, T. C. 2002. Cleared for Take-off: Structure and Strategy in the Low Fare Airline Business. Aldershot, UK: Ashgate Publishing.

Mason, K. J. 2001. Marketing low-cost airline services to business travellers, Journal of Air Transport Management 7(3): 103-109. http://dx.doi.org/10.1016/S0969-6997(00)00036-3

May, T.; Butcher, E. W. A.; Mills, G. 1986. Independent Review of Economic Regulation of Domestic Aviation: Report prepared for the minister of transport. Canberra: Australian Government Publishing Service.

Mills, G. 1989. The reform of Australian aviation, Journal of Transport Economics and Policy 23(2): 209-218.

Moens, P.; Gillies, G. 2000. International Trade and Business: Law, Policy and Ethics. Sydney: Cavendish Publishing.

Moores, V. 2009. Virgin Blue's Long-haul Arm V-Australia Commences Flights [online], [cited 12 June 2014]. Available from Internet: http://www.flightglobal.com/ articles/2009/02/27/323180/virgin-blues-long-haul-arm-vaustralia-launches-flights.html.

Morrell, P. 2008. Can long-haul low-cost airlines be successful?, Research in Transportation Economics 24(1): 61-67. http://dx.doi.org/10.1016/j.retrec.2009.01.003

Nancarrow, D. 2011. Australia gets a new budget airline, in The Sydney Morning Herald, November 3 [online], [cited
29 March 2014]. Available from Internet: http://www.smh. com.au/travel/travel-news/australia-gets-a-new-budgetairline-20111103-1mwm5.html

Nolan, J. L. (Ed.). 1996. Australia Business: the Portable Encyclopedia for Doing Business with Australia. San Rafael, CA: World Trade Press.

Nyathi, M.; Hooper, P.; Hensher, D. 1993a. Compass Airlines: 1 December 1990 to 20 December 1991 what went wrong? - Part 1, Transport Reviews 13(2): 119-149. http://dx.doi.org/10.1080/01441649308716840

Nyathi, M.; Hooper, P.; Hensher, D. 1993b. Compass Airlines: 1 December 1990 to 20 December 1991 what went wrong? Part 2. Transport Reviews 13(3): 185-206. http://dx.doi.org/10.1080/01441649308716846

Pantazis, N.; Liefner, I. 2006. The impact of low cost carriers on catchment areas of established international airports: the case of Hanover Airport, Germany, Journal of Transport Geography 14(4): 265-272.

http://dx.doi.org/10.1016/j.jtrangeo.2005.05.002

Pitt, M. R.; Brown, A. W. 2001. Developing a strategic direction for airports to enable the provision of services to both network and low-fare carriers, Facilities 19(1-2): 52-60. http://dx.doi.org/10.1108/02632770110362802

Prideaux, B. 2003. The need to use disaster planning frameworks to respond to major tourism disasters: analysis of Australia's response to tourism disasters in 2001, Journal of Travel \& Tourism Marketing 15(4): 281-298. http://dx.doi.org/10.1300/J073v15n04_04

Qantas Airways. 2004. Qantas Annual Report 2004 [online], [cited 21 December 2013]. Available from Internet: http:// www.qantas.com.au/infodetail/about/investors/2004AnnualReport.pdf

Qantas Airways. 2009. Qantas Data Book 2008/09 [online], [cited 21 December 2013]. Available from Internet: http:// www.qantas.com.au/infodetail/about/investors/qantasDataBook20082009.pdf

Qantas Airways. 2010. Qantas Data Book 2010 [online], [cited 21 December 2013]. Available from Internet: http://www. qantas.com.au/infodetail/about/investors/qantasDataBook2010.pdf

Qantas Airways. 2011. Qantas Data Book 2011 [online], [cited 21 December 2013]. Available from Internet: http://www. qantas.com.au/infodetail/about/investors/qantasDataBook2011.pdf

Qantas Airways. 2012. Qantas Data Book 2012 [online], [cited 21 December 2013]. Available from Internet: http://www. qantas.com.au/infodetail/about/investors/qantas-databook-2012.pdf

Qantas Airways. 2013. The Transformation Continues: Qantas Data Book 2013 [online], [cited 21 December 2013]. Available from Internet: http://www.qantas.com.au/ infodetail/ about/investors/qantas-data-book-2013.pdf

Quiggin, J. 1997. Evaluating airline deregulation in Australia, The Australian Economic Review 30(1): 45-56. http://dx.doi.org/10.1111/1467-8462.00004

Quinlin, H. G. 1998. Air services in Australia: growth and corporate change, 1921-1996, Australian Geographical Studies 36(2): 156-169. http://dx.doi.org/10.1111/1467-8470.00048

Rhodes, D. L. 2008. Evolution of International Aviation: Phoenix Rising. 2nd ed. Aldershot, UK: Ashgate Publishing.

Ryan, P. 2012. Air Australia grounded and placed into administration, in $A B C$ News Online, 17 February [online], [cited 29 March 2014]. Available from Internet: http:// www.abc.net.au/news/2012-02-17/air-australia-groun$\mathrm{ded} / 3835244$ ? section $=$ qld 
Shaw, S. 2011. Airline Marketing and Management. 7th ed. Farnham, UK: Ashgate Publishing.

Sinha, D. 2001. Deregulation and Liberalization of the Airline Industry: Asia, Europe, North America, and Oceania. Aldershot, UK: Ashgate Publishing.

Sobie, B. 2009. Asia to fuel Jetstar's expansion, Airline Business 25(11): 22.

Starkie, D. 2008. Aviation Markets: Studies in Competition and Regulatory Reform. Aldershot, UK: Ashgate Publishing.

Taylor, E. 2013. Virgin Australia's rule of attraction, Airline Business 29(6): 12.

Thanasupsin, K.; Chaichana, S.; Pliankarom, S. 2010. Factors influencing mode selections of low-cost carriers and a full-service airline in Thailand, Transportation Journal 49(1): 35-47.

Thomas, G. 2006a. Taking care of business, Air Transport World 43(10): 54-58.

Thomas, G. 2006b. Tiger on the prowl, Air Transport World 43(5): 46-48.

Thomas, G. 2007. Jetting to the top, Air Transport World 44(11): 57-60.

Thomas, I. 2000. Better late than never, Air Transport World 37(11): 76-77.

Thomas, I. 2003. After the honeymoon, Air Transport World 40(10): 28-31.

Tiger Airways. 2012a. Tiger Airways Operating Statistics for the Month of April 2012 [online], [cited 27 March 2014]. Available from Internet: http://www.tigerair.com/news/ TH_20120514_Tiger_Airways_Operating_Statistics_for_ the_Month_of_April_2012.pdf

Tiger Airways. 2012b. Tiger Airways Operating Statistics for the Month of May 2012 [online], [cited 27 March 2014]. Available from Internet: http://www.tigerair.com/news/ TH_20120611_Tiger_Airways_Operating_Statistics_for_ the_Month_of_May_2012.pdf

Tiger Airways. 2012c. Tiger Airways Operating Statistics for the Month of June 2012 [online], [cited 27 March 2014]. Available from Internet: http://www.tigerair.com/news/ TH_20120710_Tiger_Airways_Operating_Statistics_for_ the_Month_of_June_2012.pdf

Tiger Airways. 2012d. Tiger Airways Operating Statistics for the Month of July 2012 [online], [cited 27 March 2014]. Available from Internet: http://www.tigerair.com/news/ TH_20120810_Tiger_Airways_Operating_Statistics_for_ July_2012.pdf

Tiger Airways. 2012e. Tiger Airways Operating Statistics for the Month of August 2012 [online], [cited 27 March 2014]. Available from Internet: http://www.tigerair.com/news/ TH_20120910_Tiger_Airways_Operating_Statistics_for_ August_2012.pdf

Tiger Airways. 2012f. Tiger Airways Operating Statistics for the Month of September 2012 [online], [cited 27 March 2014]. Available from Internet: http://www.tigerair.com/news/ TH_20121011_Sep_12_Operating_Statistics.pdf

Tiger Airways. 2012g. Tiger Airways Operating Statistics for the Month of October 2012 [online], [cited 27 March 2014]. Available from Internet: http://www.tigerair.com/news/ TH_20121112_Oct_2012_Operating_Statistics.pdf

Tiger Airways. 2012h. Tiger Airways Operating Statistics for the Month of November 2012 [online], [cited 27 March 2014]. Available from Internet: http://www.tigerair.com/news/ OS_20121210_Nov_2012_Operating_Statistics.pdf

Tiger Airways. 2013a. Tiger Airways Operating Statistics for the Month of December 2012 [online], [cited 27 March 2014]. Available from Internet: http://www.tigerair.com/
news/TH_20130111_Tiger_Airways_Operating_Statistics_Dec_2012.pdf

Tiger Airways. 2013b. Tiger Airways Operating Statistics for the Month of January 2013 [online], [cited 27 March 2014]. Available from Internet: http://www.tigerair.com/ news/TH_20130218_Tiger_Airways_Operating_Statistics_Jan_2013.pdf

Tiger Airways. 2013c. Tiger Airways Operating Statistics for the Month of February 2013 [online], [cited 27 March 2014]. Available from Internet: http://www.tigerair.com/ news/TH_20130813_Tiger_Airways_Operating_Statistics_Feb_2013.pdf

Tiger Airways. 2013d. Tiger Airways Operating Statistics for the Month of March 2013 [online], [cited 27 March 2014]. Available from Internet: http://www.tigerair.com/ news/TH_20130813_Tiger_Airways_Operating_Statistics_Mar_2013.pdf

Tiger Airways. 2013e. Tiger Airways Operating Statistics for the Month of April 2013 [online], [cited 27 March 2014]. Available from Internet: http://www.tigerair.com/news/ TH_20130813_Tiger_Airways_Operating_Statistics_ Apr_2013.pdf

Tiger Airways. 2013f. Tiger Airways Operating Statistics for the Month of May 2013 [online], [cited 27 March 2014]. Available from Internet: http://www.tigerair.com/news/ TH_20130813_Tiger_Airways_Operating_Statistics_ May_2013.pdf

Tiger Airways. 2013g. Tiger Airways Operating Statistics for the Month of June 2013 [online], [cited 27 March 2014]. Available from Internet: http://www.tigerair.com/news/ TH_20130813_Tigerair_Operating_Statistics_Jun13.pdf

Tiger Airways. 2014. Where we Fly [online], [cited 27 March 2014]. Available from Internet: http://www.tigerair.com/au/ en/destination_map.php

Vasigh, B.; Tacker, T.; Fleming, K. 2008. Introduction to Air Transport Economics: from Theory to Applications. Aldershot, UK: Ashgate Publishing.

Vidović, A.; Štimac, I.; Vince, D. 2013. Development of business models of low-cost airlines, International Journal for Traffic and Transportation Engineering 3(1): 69-81. http://dx.doi.org/10.7708/ijtte.2013.3(1).07

Virgin Australia. 2011a. Virgin Australia Annual Report 2011 [online], [cited 21 December 2013]. Available from Internet: http://www.virginaustralia.com/cs/groups/internetcontent/@wc/documents/webcontent/ edisp/annual-rpt-2011.pdf

Virgin Australia. 2011b. Virgin Australia Re-brands its International Airlines. Press Release. 7 December [online], [cited 3 May 2014]. Available from Internet: http://www.virginaustralia.com/au/en/about-us/media/2011/VIRGIN-AUSTRALIA-RE-BRANDS/

Virgin Australia. 2012. Virgin Australia Annual Report 2012 [online], [cited 21 December 2013]. Available from Internet: http://www.virginaustralia.com/cs/groups/internetcontent/@wc/documents/webcontent/ edisp/annual-rpt-2012.pdf

Virgin Australia. 2013. Virgin Australia Annual Report 2013 [online], [cited 21 December 2013]. Available from Internet: http://www.virginaustralia.com/cs/groups/internetcontent/@wc/documents/webcontent/ edisp/annual-rpt-2013.pdf

Virgin Blue. 2004. Virgin Blue Annual Report 2004 [online], [cited 21 December 2013]. Available from Internet: http:// www.virginaustralia.com/cs/groups/internetcontent/@wc/ documents/webcontent/ edisp/annual-rpt-2004-a3.pdf 
Virgin Blue. 2005. Virgin Blue Annual Report 2005 [online], [cited 21 December 2013]. Available from Internet: http:// www.virginaustralia.com/cs/groups/internetcontent/@wc/ documents/webcontent/ edisp/annual-rpt-2005.pdf

Virgin Blue. 2006a. Virgin Blue Annual Report 2006 [online], [cited 21 December 2013]. Available from Internet: http:// www.virginaustralia.com/cs/groups/internetcontent/@wc/ documents/webcontent/ edisp/annual-rpt-2006.pdf

Virgin Blue. 2006b. Virgin Blue Orders 20 Embraer 'E-Jets' New Fleet Strategy for Australia's 'New World Carrier'. Press Release November 2 [online], [cited 3 May 2014]. Available from Internet: http://www.virginaustralia.com/au/ en/about-us/media/2006/VB_ORDERS_20_EMBRAER_ JETS/

Virgin Blue. 2007. Virgin Blue Annual Report 2007 [online], [cited 21 December 2013]. Available from Internet: http:// www.virginaustralia.com/cs/groups/internetcontent/@wc/ documents/webcontent/ edisp/annual-rpt-2007.pdf

Virgin Blue. 2008. The Report: Annual Report 2008 [online], [cited 21 December 2013]. Available from Internet: http:// www.virginaustralia.com/cs/groups/internetcontent/@wc/ documents/webcontent/ edisp/annual-rpt-2008.pdf

Virgin Blue. 2009. The Report: Annual Report 2009 [online], [cited 21 December 2013]. Available from Internet: http:// www.virginaustralia.com/cs/groups/internetcontent/@wc/ documents/webcontent/ edisp/annual-rpt-2009.pdf

Virgin Blue Holdings. 2010. Virgin Blue Holdings Annual Report 2010 [online], [cited 21 December 2013]. Available from Internet: http://www.virginaustralia.com/cs/groups/ internetcontent/@wc/documents/webcontent/ edisp/annual-rpt-2010.pdf

Wensveen, J. G.; Leick, R. 2009. The long-haul low-cost carrier: a unique business model, Journal of Air Transport Management 15(3): 127-133.

http://dx.doi.org/10.1016/j.jairtraman.2008.11.012 